\title{
Employees' preference for the on- site childcare service: a case study of three Sri Lankan apparel firms
}

\author{
B.M.A.M. Balasooriya and Asankha Pallegedara
Department of Industrial Management, Wayamba University of Sri Lanka, \\ B.M.A.M. Balasooriya and Asankha Pallegedara
Department of Industrial Management, Wayamba University of Sri Lanka, \\ Kuliyapitiya, Sri Lanka
} Kuhisitisa, Sri Lanka

\begin{abstract}
Purpose-Childcare is one of the main obstacles for women to enter the labour market as they are the primary caregivers for children. The struggle between childcare and women's employment has caused a high labour turnover in women-dominated industries. The aim of this study is to assess the employees' willingness for an on-site childcare facility

Design/methodology/approach - The primary goal of this study was to assess the employees' willingness for an on-site childcare facility using the contingent valuation method. For the analysis, 330 data were collected from all levels of the employees in three firms in the apparel industry using a survey-based questionnaire.

Findings - The results illustrate that the mean willingness to pay for the on-site childcare facility is substantially higher for the firm that already provide an on-site childcare facility than the other two firms that do not have childcare facilities. Among all employees who are surveyed, $86.36 \%$ of the employees favoured implementation of on-site childcare facilities. According to the survey findings, the newly hired employees have a higher preference for the childcare facility, however less likely to pay for the facility. The monthly income variable has a negative association with the probability of voting in favour of implementing on-site childcare facility. Moreover, the results indicate that the employees who have received the childcare facility have positive attitudes towards the on-site childcare facility.

Originality/value - To the authors' knowledge, prior case studies related to the evaluation of employee's preference for on-site childcare services have not been conducted in the context of industries in Sri Lanka. Therefore, the findings and implications were discussed while expanding the geographical scope of the past literature.
\end{abstract}

Keywords Women employment, Childcare, On-site childcare, Willingness to pay, Sri Lanka, Apparel industry Paper type Research paper

\section{Introduction}

Over the last few decades, female's labour force participation as employees have reached $58.6 \%$ in Sri Lanka (Sri Lanka Labour Force Survey, 2019). Economic changes in the country have caused an increase in the contribution of women's workforce in several industries over the years. With the continuous rise in commodity prices and other household costs, it has become arduous to support the family needs with one family member's income. It has resulted in women's participation in the country's labour force, leading to an increase in the women's labour market in Sri Lanka. Among many industries in Sri Lanka, the apparel industry has become one of the primary income sources of the country with the increased domination in the mentioned industry workforce.

\section{JEL Classification — D23, J20, J28}

(C) B.M.A.M. Balasooriya and Asankha Pallegedara. Published in Journal of Asian Business and Economic Studies. Published by Emerald Publishing Limited. This article is published under the Creative Commons Attribution (CC BY 4.0) licence. Anyone may reproduce, distribute, translate and create derivative works of this article (for both commercial and non-commercial purposes), subject to full attribution to the original publication and authors. The full terms of this licence may be seen at http:// creativecommons.org/licences/by/4.0/legalcode

The authors would like to thank three apparel firms that gave consent to collect data from their employees. The authors also like to thank the Editors of the journal and anonymous reviewers for their insightful comments, which greatly helped them to improve the quality of the paper.

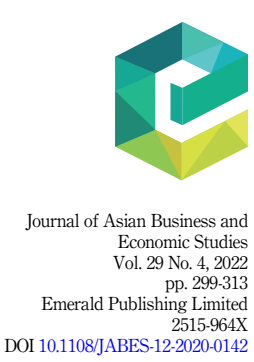

Received 17 December 2020 Revised 11 March 2021 27 May 2021 29 May 2021 Accepted 3 June 2021

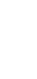


JABES 29,4

300

As women are the primary caregivers of children according to the Sri Lankan family constitution, it has become one of the many reasons that prevent women from entering the labour market. According to the World Bank report, 2017, it is observed that women's labour participation has reduced due to the presence of children under age five (Solotaroff et al., 2020). According to the Department of Census and Statistics of Sri Lanka, the total unemployment rate in 2018 was $4.6 \%$, whereas the female unemployment rate was $7.1 \%$ compared to the male unemployment rate of $3.2 \%$. Unemployment rates by educational level for both men and women depict a more precise clearer image than merely uttering the unemployment rates of men and women.

According to Figure 1, although both men and women have the same educational qualifications, the women's unemployment rate is higher than the men's employment rate, whereas the women's unemployment rate shows an aggressive increase compared to male unemployment when the educational level increases. Conversely, men have a relatively steady unemployment rate than women regardless of educational level.

Table 1 shows the women's employment in Sri Lanka between the years 2012-2018 according to their age groups. According to the Department of Census and Statistics data, women's labour participation has decreased between the years 2012-2018 in the age group of 20-39 yrs. However, women's labour participation in the age group of 40 and above has increased over the years from 2012 to 2018 .

Demographic and Health Survey (2016) has stated that the age of 25-34 years is the age group with the highest fertility rate in women in Sri Lanka, highlighting that childcare

Figure 1.

Unemployment rates by gender and level of education

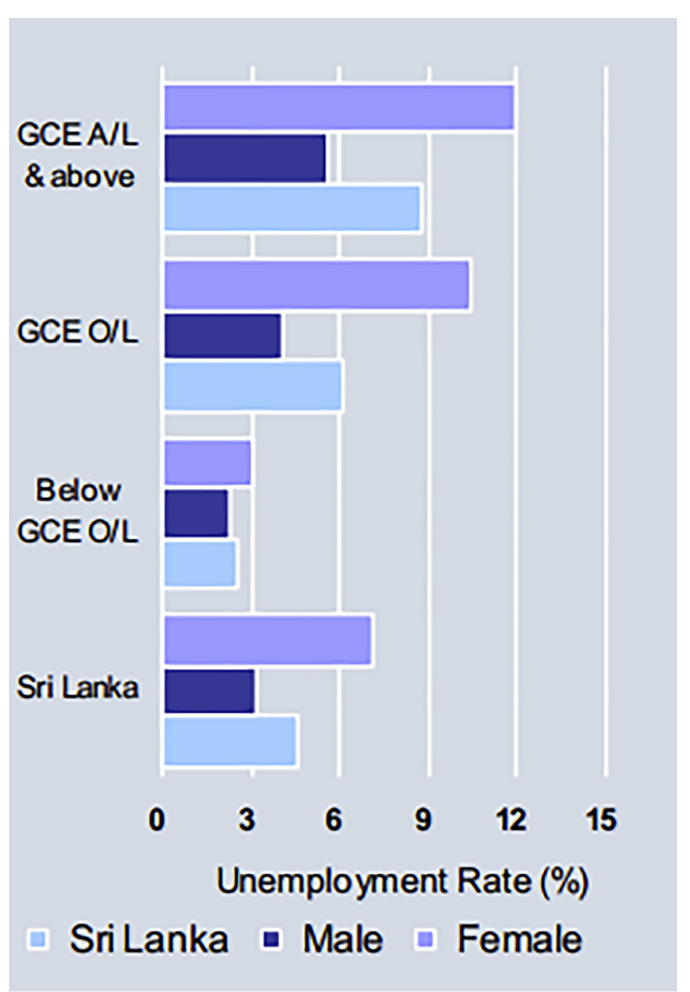

Source(s): Department of Census and Statistics, 2018 


\begin{tabular}{|c|c|c|c|c|c|c|c|}
\hline Year & All ages & 15-19 YRS & 20-24 YRS & $\begin{array}{c}\text { Age groups } \\
25-29 \text { YRS } \\
\end{array}$ & 30-39 YRS & $40+$ YRS & $\begin{array}{l}\text { Willingness to } \\
\text { pay for On-site }\end{array}$ \\
\hline $2012^{1}$ & 100.0 & 2.2 & 8.4 & 10.5 & 25.1 & 53.8 & \\
\hline $2013^{1}$ & 100.0 & 2.4 & 8.0 & 10.0 & 24.3 & 55.3 & \\
\hline $2014^{1}$ & 100.0 & 2.2 & 7.1 & 9.9 & 24.8 & 56.0 & \\
\hline $2015^{1}$ & 100.0 & 2.1 & 7.8 & 9.6 & 24.7 & 55.9 & \\
\hline $2016^{1}$ & 100.0 & 1.6 & 7.2 & 9.6 & 24.3 & 57.3 & 301 \\
\hline $2017^{1}$ & 100.0 & 1.7 & 7.8 & 9.0 & 23.2 & 58.3 & \\
\hline $2016 \mathrm{Q} 4^{1}$ & 100.0 & 1.4 & 7.4 & 9.0 & 25.0 & 57.2 & \\
\hline $2017 \mathrm{Q} 4^{1}$ & 100.0 & 1.1 & 8.6 & 9.7 & 21.3 & 59.3 & \\
\hline $2018 \mathrm{Q} 1^{1}$ & 100.0 & 1.4 & 6.6 & 7.8 & 23.6 & 60.6 & \\
\hline $2018 \mathrm{Q} 2^{1}$ & 100.0 & 1.6 & 6.2 & 8.2 & 21.2 & 62.7 & \\
\hline $2018 \mathrm{Q} 3^{1}$ & 100.0 & 1.7 & 7.0 & 8.5 & 23.7 & 59.1 & \\
\hline $2018 \mathrm{Q} 4^{1}$ & 100.0 & 1.1 & 7.8 & 8.5 & 22.2 & 60.4 & $\begin{array}{l}\text { Table } 1 . \\
\text { Percentage of women }\end{array}$ \\
\hline \multicolumn{7}{|c|}{$\begin{array}{l}\text { Note(s): }{ }^{1} \text { - All the districts are included and the tables consist with reweighted estimates } \\
\text { Source(s): Department of Census and Statistics, } 2018\end{array}$} & $\begin{array}{r}\text { employment by } \\
\text { age group }\end{array}$ \\
\hline
\end{tabular}

responsibility is a barrier to women's employment. Most females try to be employed due to the economic status of the family. However, with busy schedules at work, women find it challenging to manage childcare at home. It can cause work/family conflicts which will result in quitting their jobs to care for children.

To narrow the gender gap in labour participation, providing on-site childcare can be used as an effective strategy. It has now been implemented in a few firms in the Sri Lankan apparel sector. Providing on-site childcare can be added as a part of employee benefits which will become a powerful motivation for women to join the labour market. With the employer's support for childcare, women can balance both work and childcare. Some companies offer this benefit at employees' expenses who have enrolled their children in an on-site childcare centre, while others offer it for free. It has resulted in a higher rate of women's labour participation in the Sri Lankan apparel industry, and it can increase the efficiency of the workforce and reduce absenteeism and labour turnover. Implementing on-site childcare can give endless family benefits to women. According to Solotaroff et al. (2020), Sri Lankan companies that offer on-site childcare facilities have positively influenced the recruitment, productivity and retention of female employees.

Analysis reports related to employees' preference for on-site care facilities are still limited. As the first study that directs on this problem, Connelly et al. (2004a, b) have calculated the value of employer-sponsored childcare services offered to employees. They have found that the price of childcare service is a determinant of willingness to pay for the continued existence or establishment of an on-site childcare centre. To the best of our knowledge, there has not been a documented study analysing the employees' preference for on-site childcare facilities in the Sri Lankan context. The primary objective of this paper is to evaluate the employees' preference for on-site childcare facilities in Sri Lanka.

The rest of the paper is organized as follows. Section 2 discusses the literature related to childcare and women's labour participation. Section 3 explains the materials and methods used in this study. Section 4 presents the results and discusses them. Section 5 concludes the paper by discussing policy recommendations.

\section{Literature review}

\subsection{Impact of childcare availability and childcare costs on women labour participation}

Considering the availability of childcare in the local area as a ratio to women's participation in the labour market, Stolzenberg and Waite (1984) have found that the availability of childcare 
JABES 29,4

302

services significantly affects women's participation in the labour market. The study is based on the 409 areas using the 1970 census data and has researched childcare costs, childcare availability and job convenience. The authors have identified that childcare costs, childcare availability and the convenience of the job affect women's labour force participation. Women enter the labour market mainly to overcome the economic problems of the family. Without a way to take care of their children, women may enrol children in public childcare centres that are higher in cost.

Connelly (1992) has examined childcare costs with the probability of women's participation in the labour market. The author has found that the increase in childcare costs reduces women's labour participation. Observed results from this study conclude that the relatives and spouse as the childcare providers reduce the rise in childcare costs.

Using the National Survey of Families and Households (NSFH) and the public use files of the US Census datasets, Compton and Pollak (2014) have studied the proximity of labour participation of young women who have children living with their mothers or mothers-in-law. They have also identified a positive impact on women's labour participation who have children living with their mothers or mothers-in-law. The defined mechanism is where availability to provide childcare during employment hours can highly affect women's labour participation. This shows that if family members are available to meet childcare needs, women's labour participation can increase comparatively. Floge (1989) has identified that when the family members act as childcare providers, it can positively affect the women's labour force participation. This study is based on the four-year longitudinal study of New York City mothers. The author has found that the employment rate of the women living alone with their children is less than the employment rate of women living in a large household with the availability of childcare providers. Furthermore, with the data from China Health and Nutrition Survey in 1991, Chen et al. (2000) have declared that the residence of grandparents can positively impact on the mother's involvement in childcare activities. Grandparents living in the same household or nearby residences have decreased the mother's participation in childcare. These findings illustrate the importance of grandparents as childcare providers.

According to Duflo (2012), childcare is primarily carried out by women rather than men in developing countries. By studying 23 countries from the Multinational Use Study and 12 under-developed countries, Berniell and Sánchez-Páramo (2011) have found that women are responsible for more housework and care and women's employment rate in those countries is low. The authors have stated that the housework and childcare are performed by women rather than men in countries like Cambodia, Guinea and Sweden. These differences can withdraw women from joining the labour market. As a result, most women in developing countries engage in informal jobs that may not be the most productive use of their time. Due to the government support for childcare costs in most European countries and reduced gender inequality at workplaces, those countries display a higher rate in women's employment (Hein and Cassirer, 2010).

\subsection{Impact of on-site childcare facility on employee performance}

As an employee incentive, some organizations have implemented a strategy called on-site childcare centres for employees. It is more beneficial to employees with children who need constant caregiving. Milkovich and Gomez (1976) have studied the relationship between the childcare facility and the employee work behaviours in the United States, and they have considered absenteeism, turnover and job performance as the three indices of work behaviour. Their study found that job performance is not directly linked with the availability of childcare facilities, while there is low absenteeism and turnover concerning enrolment in the childcare program. This suggests that the childcare program is not the employer's social responsibility. However, it is beneficial to employers in managing employee behaviours like turnover and absenteeism through a childcare program. 
Anderson and Geldenhuys (2011) have studied the relationship between on-site childcare and absenteeism. They have found that there is a negative relationship between absenteeism and on-site childcare. Their study has considered several demographic variables like gender, age, marital status and race. There is a significant difference in marital status and age concerning absenteeism, while there is no significant difference in gender and race. The authors have concluded that providing on-site childcare is a better strategy to manage absenteeism in the South African work context, and the cost of implementing on-site childcare can be covered by reducing the rate of absenteeism.

Narayanan (2008) has studied the impact of the National Rural Employment Guarantee Act (NREGA) on the lives of female employees and their families. The promise of NREGA is a solution for the childcare challenge faced by women labour in Tamil Nadu. This study covered 11 villages and 15 NREGA worksites and interviewed 104 women who had at least one child under six years old. According to the promise of NREGA, if there are at least five children under the age of six years at the worksite, one of the female workers should be appointed to look after those children, and the same salary should be paid to her. The study found that the NREGA promise has positively affected women's labour and their families, and it has offered a happy, comfortable life. In addition, having on-site childcare facilities can attract and retain male workers in the specific workplace as their wives can also enter the labour market while enrolling their children in the on-site childcare centre at the workplace of their fathers.

\subsection{Women labour participation in Sri Lanka}

According to Samarakoon and Mayadunne (2018), $72 \%$ of women who are married and have children and $40.1 \%$ of women who are single and have children were unemployed in Sri Lanka. The study was conducted using qualitative and quantitative analysis. Quantitative data were collected from the 2014 Labour Force Survey, and Household Income and Expenditure Surveys of the Department of Census and Statistics (2012/13) and the qualitative data were collected through interviews.

Chowdhury (2013) has studied the contributory factors that can affect low female labour force participation in Sri Lanka. Their study states that married women have a high desire to quit the labour force, and there is a 34\% increased risk of quitting labour force once a woman gets married. Furthermore, they have stated that among married women without children under ten years old, $56 \%$ of women from rural areas and $66 \%$ of women in urban areas are unemployed. Among married women who have at least one child under ten years old, $68 \%$ of women from rural areas and $73 \%$ of women in urban areas are unemployed. This shows that the probability of being unemployed is higher in married women with children under ten years old than married women without children under ten years old.

\subsection{Impact of out-of-home childcare on child's development}

Using a longitudinal study of 146 children aged 16 months, Broberg et al. (1997) has stated that the children who spent at least 36 months in out-of-home childcare had received high scores in cognitive ability tests in Sweden. By undertaking a long-term longitudinal study in Sweden, Anderson $(1989,1992)$ has found that early out-of-home childcare can positively affect the child's cognitive development and the teacher's ratings for the performance of the child. The study was conducted through follow-up assessments of the child at age eight and 13 years. On the contrary, through a series of meta-analyses, Erel et al. (2000) have declared that the children who experienced non-maternal care do not differ from the children who experienced maternal care on seven indices of child outcomes. Among those seven indices, the first three indices were related to the mother-child bond. 
JABES

29,4

304

\section{Materials and methods}

\subsection{Data}

This study is targeting only three apparel firms (company A, company B and company C), which are not subsidiary companies. These three companies are in the same geographical area, which faces the same childcare market. Among these three companies, one company (company C) had an on-site childcare facility, while the other two companies (company A and company B) did not have a childcare facility at the time of the survey. About 2,500 employees are working in all three companies.

Data needed for the study were collected through a survey-based questionnaire. The sampling method used to collect data for the study is the convenience sampling method. Morgan's table was used to select the sample size from the total employees of the three companies. The study's sample size is 330 for the population of 2500 (Krejcie and Morgon, 1970). The collected data were the primary data for the study. Gaining access to three large firms in the same industry consistent with the experimental design of "treatment and control" was challenging as it is disturbing the firm's production. Therefore, the questionnaire was created with multiple-choice questions.

The supplementary discussions were also conducted with the managers of the two firms without childcare facilities to recognize their opinion on the space and capital availability of the firm to implement the facility. This was conducted to know the firms' view point of establishing an on-site childcare facility. In addition, details about the already established childcare centre of the company $\mathrm{C}$ was collected from the human resources manager in company $\mathrm{C}$.

\subsection{Empirical estimation}

According to O'Doherty (1996), the contingent valuation method is used in current practices of public participation exercises in developing local plans using empirical and theoretical arguments. The contingent valuation method is an evaluation method that consists of a questionnaire-based technique and is highly used in evaluating non-marketed goods or resources. Furthermore, Hanemann (1994) has stated that the contingent valuation method is a conceptual link to non-market valuation if there is no market for a good or resource, and the demand curve is not observable. Further, the author has identified that the contingent valuation method can be used to measure people's value for the environment. Monetary valuation for a private good can be derived by directly observing the purchasing behaviour and prices. However, if it is a public good, it is difficult to derive the monetary value of a commodity through direct observation. Connelly et al. (2004a, b) have found that the contingent valuation model is appropriate to measure the value of childcare facilities to employees. Assuming that the amount an employee is willing to pay is equal to how much the facility is beneficial for him, the authors have calculated the value of the childcare facility.

Using the contingent valuation method, the researcher asked the respondent about the individual's monetary valuation for a particular commodity. This study consists of an openended contingent valuation method, which gives the respondent the freedom to choose how much they will pay. The opened-ended contingent valuation method is less liable to hypothetical bias than the closed-ended contingent valuation method (Kealy and Turner, 1993). This paper adopts the approach used by Connelly et al. (2004a, b). However, the dissimilarity is that this paper uses the open-ended contingent valuation method.

For this study, a probit regression equation can be written as follows with $n$ independent variables as $X_{1}, X_{2}, \ldots, X_{n}$, and a dependent variable $Y$,

$$
Y=\beta_{0}+\beta_{1} x_{1}+\beta_{2} x_{2}+\cdots+\beta_{n} x_{n}+\varepsilon
$$

where $\beta_{0}$ is the value of the dependent variable $Y$ when all the independent variables 
$X_{1}, X_{2}, \ldots, X_{n}$ are equal to zero and $\beta_{1}, \beta_{2}, \ldots, \beta_{n}$ are the estimated regression coefficients, which represent the change in the dependent variable $Y$ relative to a one-unit change in the respective independent variable. The $\varepsilon$ denotes the residual term of the model.

According to this study, the dependent variable is $Y$, which represents the preference to have the childcare facility. The independent variables of the study are age, gender, marital status, monthly income, educational level, service period, miles to work, having children under 16 years old and having children under four years old.

The explanatory variables used in the study are selected according to previous studies. 1998). Some studies have found that certain factors related to the family can influence the work of an employee. Blegen et al. (1988) and Waite et al. (1985) have found that sex can affect the family at work. The marital status (Frone et al., 1992; Lobel and Clair 1992), age and education (Cohen et al., 2013; Miller, 1984) also can influence the work-family area. The rest of the explanatory variables are considered according to the study of Connelly et al. (2004a, b). The questionnaire was built based on these explanatory variables to evaluate the willingness of the employees for an on-site childcare facility.

\section{Results and discussion}

\subsection{Descriptive statistics}

To commence the study into how willingness to pay for an on-site childcare facility can differ among employees and firms, the characteristics of the surveyed employees are presented in Table 2. It is evident from Table 2 that the firm which already provides on-site childcare has a higher percentage of voting yes for providing on-site childcare than the other two firms. Further, it shows that the number of female employees and married employees in the above mentioned firm are higher in percentages compared to the other two firms. The primary purpose of providing on-site childcare is to attract marginal labour market participants into the labour force (Connelly et al., 2004a, b). These descriptive results have proven it with the percentage differences in married employees, female employees and the female employees of the age group 20-39 years Table 1 explicitly states that there is a decrease in the women's employment rate in the age group from 20 to 39 years. Among the three firms, company C, with an on-site childcare centre, has a higher percentage of female employees from age 20 39 years.

In the data sample, $64.9 \%$ of the female employees aged from 20 - 39 years are the employees without children below 16 years old. It is the age that most women face their pregnancies and have small children. Proving the phenomenon, the study sample also indicates a higher percentage of female employees aged from 20 - 39 years who do not have children below 16 years old. This reveals that childcare is a barrier for women to enter the labour force in the apparel industry. According to the descriptive results, the average number of employees having children under four years old and 16 years old in company $\mathrm{C}$ is prominent compared to the other two firms. It suggests that company $\mathrm{C}$ succeeds at recruiting and retaining the employees having children who need parental care. As there are substantial differences in several variables across three firms, the analysis is done separately from each three firms.

\subsection{Contingent valuation bid distribution for on-site childcare facility}

The responses of the employees for price distributions used in the study are provided in Table 3. It summarizes the responses for each price category and indicates the percentage values to visualize the differences between the three firms for each category. In the study, respondents were given a set of price ranges and asked to choose one price category 


\begin{tabular}{|c|c|c|c|c|c|}
\hline \multirow{2}{*}{ JABES } & & \multirow[b]{2}{*}{ Company A } & \multirow[b]{2}{*}{ Company B } & \multirow[b]{2}{*}{ Company C } & \multirow[b]{2}{*}{ All } \\
\hline & & & & & \\
\hline \multirow{5}{*}{306} & Percent voting "Yes" for on-site childcare & 77.46 & 79.35 & 93.75 & 86.36 \\
\hline & $\begin{array}{l}\text { Mean number of employees having children less than } \\
16\end{array}$ & 0.37 & 0.41 & 0.45 & 0.41 \\
\hline & Mean number of employees having children less than 4 & 0.13 & 0.12 & 0.23 & 0.16 \\
\hline & Percent college graduates & 25.23 & 3.26 & 23.96 & 17.88 \\
\hline & Marital status & & & & \\
\hline \multirow{10}{*}{$\begin{array}{l}\text { Table } 2 \text {. } \\
\text { Selected descriptive } \\
\text { statistics of the } \\
\text { three firms }\end{array}$} & Percent married & 52.11 & 38.04 & 66.67 & 52.42 \\
\hline & Percent never married & 47.89 & 61.96 & 33.33 & 47.58 \\
\hline & Percent female between $20-39$ yrs & 69.15 & 62.12 & 88.16 & 74.36 \\
\hline & Gender & & & & \\
\hline & Percent female & 66.20 & 71.74 & 79.17 & 70.91 \\
\hline & Percent male & 33.80 & 28.26 & 20.83 & 29.09 \\
\hline & Mean service period & 5.96 & 7.29 & 4.52 & 5.92 \\
\hline & Percent newly hired employees & 38.73 & 27.17 & 45.83 & 37.58 \\
\hline & Number of employees surveyed & 142 & 92 & 96 & 330 \\
\hline & Source(s): Authors' calculation based on survey data & & & & \\
\hline
\end{tabular}

according to their preferences. Table 3 shows how the surveyed employees have responded to the given question. It includes the number of employees who voted yes for providing childcare facilities as a percentage of the employees who selected the relevant price category and the percentage of employees who selected each price category.

The response pattern of the employees shows that if an employee has a high preference for the childcare facility, he will be choosing a higher price category than an employee with a low preference for the facility. In the study evaluating the theoretical validity of willingness to pay, Braun et al. (2016) have declared that the respondents who "strongly disagree" and "somewhat disagree" with something would state a higher willingness to pay for the avoidance of that.

Excluding the responses of voting for not paying any amount for the facility, in both company A and company B, the majority selected the price range Rs. 1-Rs. 5000. However, the employees in company $\mathrm{C}$ have selected the price range Rs. 5001-Rs. 10,000, which is higher than the range reported from the other two firms. Previous studies have found that the employees who do not receive the on-site childcare facility have less positive attitudes towards the facility than the employees who receive the benefit (Goff et al., 1990; Kossek and Nichol, 1992). This endorses the validity of data in the study.

\begin{tabular}{|c|c|c|c|c|c|c|c|c|c|}
\hline \multirow{2}{*}{$\begin{array}{l}\text { Given } \\
\text { price } \\
\text { ranges } \\
\text { (Rs) }\end{array}$} & \multicolumn{3}{|c|}{ Company A } & \multicolumn{3}{|c|}{ Company B } & \multicolumn{3}{|c|}{ Company C } \\
\hline & $n$ & $\begin{array}{l}\text { Percent of } \\
\text { preference }\end{array}$ & $\begin{array}{l}\text { Percent } \\
\text { of total }\end{array}$ & $n$ & $\begin{array}{l}\text { Percent of } \\
\text { preference }\end{array}$ & $\begin{array}{l}\text { Percent } \\
\text { of total }\end{array}$ & $n$ & $\begin{array}{l}\text { Percent of } \\
\text { preference }\end{array}$ & $\begin{array}{l}\text { Percent } \\
\text { of total }\end{array}$ \\
\hline 0 & 67 & 36.36 & 47.18 & 33 & 20.55 & 35.87 & 30 & 31.11 & 31.25 \\
\hline $1-5000$ & 58 & 52.73 & 40.85 & 58 & 78.08 & 63.04 & 27 & 27.78 & 28.13 \\
\hline $\begin{array}{l}5001- \\
10,000\end{array}$ & 17 & 10.91 & 11.97 & 1 & 1.37 & 1.09 & 39 & 41.11 & 40.63 \\
\hline Total & 142 & 77.46 & 100 & 92 & 79.35 & 100 & 96 & 93.75 & 100 \\
\hline
\end{tabular}


4.3 Marginal effects on the probability of voting “yes" to provide childcare facility

Table 4 presents the estimation results of the probit model.

The contingent valuation "price" for the on-site childcare centre is positive in all three firms. As mentioned above, during the survey, respondents were given the price ranges to select according to their preferences. If a respondent has chosen a higher price range, it can be deducted that his preference towards the establishment of a childcare facility is high. In Table 4, the monthly income of an employee is considered as an explanatory variable. For both the companies $\mathrm{A}$ and $\mathrm{B}$, the monthly income variable is not significant. However, for company $\mathrm{C}$, the monthly income variable is negatively significant. Chaudry et al. (2011) have stated that low-income family workers have faced significant childcare constraints due to their employment context. Moreover, they have declared that informal working hours and unpaid leaves can greatly affect the childcare constraints. Therefore, it can be understood that low-income employees have a significant need for an on-site childcare facility. This implies that an employee's income and the preference towards paying for the on-site childcare facility have a negative correlation.

Further, the variable "newly hired employees" has a positive correlation in all three firms. This shows that newly hired employees are more likely to support having a childcare facility. Few coefficients are significant in each of the three firms, and those significant variables are not standard for all three firms.

\subsection{Mean willingness to pay for on-site childcare centre}

Table 5 shows the employee valuations of on-site childcare facilities by a selected set of worker characteristics.

These results are based on the contingent valuation method question in the study. Table 5 provides the mean willingness to pay values for the on-site childcare centre per monthly paycheck. As shown in Table 5, the mean values for the full sample indicate the average willingness to pay the amount for each of the three firms separately. The mean willingness to

\begin{tabular}{|c|c|c|c|}
\hline & Company A & Company B & Company C \\
\hline $\begin{array}{l}\text { Contingent valuation "price" for on-site } \\
\text { childcare }\end{array}$ & $0.0001(0.0002)$ & $0.0002(0.0001)^{* * * *}$ & $0.0101(0.0185)$ \\
\hline Male employees & $-0.0818(0.0987)$ & $-0.0316(0.0639)$ & $-0.0647(0.0767)$ \\
\hline Monthly income of an employee & $0.0007(0.0007)$ & $-0.0026(0.0034)$ & $\begin{array}{c}-0.0001(0.0178) \\
* * *\end{array}$ \\
\hline Having children below 4 years old & $-0.2459(0.2599)$ & $0.1082(0.0894)$ & $0.3960(0.1228)^{* * * *}$ \\
\hline Having children below 16 years old & $0.3458(0.1376)^{* *}$ & $0.0645(0.0708)$ & $-0.0087(0.0466)$ \\
\hline Graduate employees & NA & NA & $2.6244(0.8813)^{* * * *}$ \\
\hline Employees who live less than $10 \mathrm{~km}$ & $0.1632(0.0981)^{*}$ & $\begin{array}{c}-0.1623(0.0638) \\
* *\end{array}$ & $-0.0142(0.5422)$ \\
\hline Married employees & $-0.1522(0.0877)$ & $0.1970(0.0616)^{* * *}$ & $0.9491(0.2766)^{* * * *}$ \\
\hline Employees of age $20-39$ years old & $0.0191(0.0830)$ & $\begin{array}{c}-0.1468(0.0693) \\
* *\end{array}$ & $0.0283(0.0610)$ \\
\hline Newly hired employees & $0.0598(0.0982)^{*}$ & $0.0114(0.0714)^{*}$ & $0.0023(0.4742)^{*}$ \\
\hline$n$ & 109 & 89 & 96 \\
\hline Log likelihood & -58.095 & -19.183 & -15.905 \\
\hline Chi squared & 12.62 & 44.39 & 19.33 \\
\hline
\end{tabular}

Note(s): The sample sizes vary slightly across tables owing to missing data for selected variables (Standard errors are in parenthesis)

Source(s): Authors' calculation based on survey data
Willingness to pay for On-site Childcare 
JABES

29,4

308

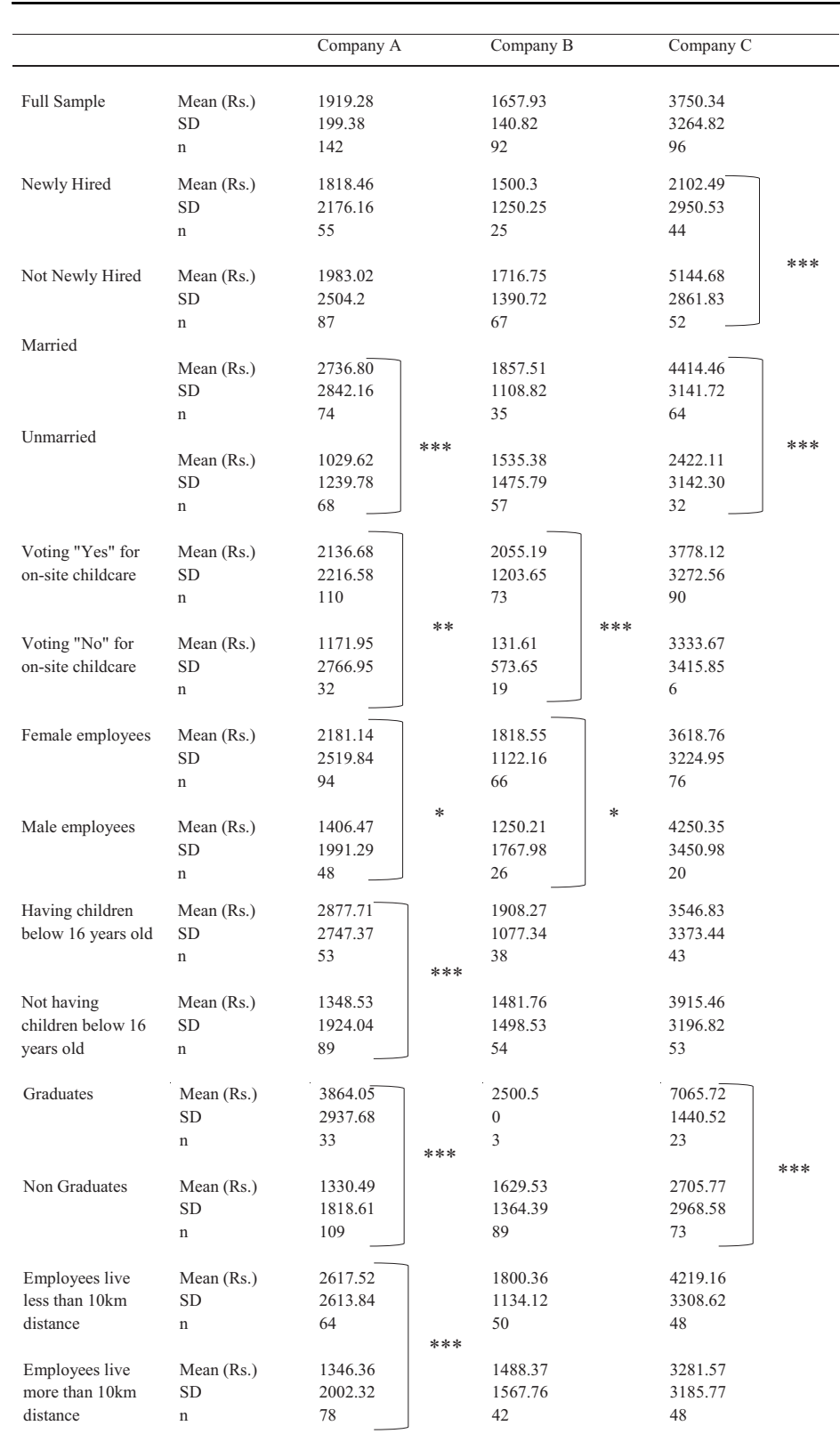

Table 5.

Mean Willingness to

Pay for On-site

Childcare by Selected

Characteristics

* Indicates that significant differences were found at the levels denoted below

*Significantly different at 10 percent level

**Significantly different at 5 percent level

*** Significantly different at 1 percent level

Source(s): Authors' calculation based on survey data 
pay in the two firms, company A and company B, which do not have childcare centres are Rs. 1919.28 and Rs. 1657.93 per month, respectively. The mean willingness to pay in the firm that has the on-site centre is significantly higher than the other two firms, which is Rs. 3750.34 per month. The difference between companies $\mathrm{A}$ and $\mathrm{B}$ is not statistically significant.

The statistical difference across the characteristics of employees can be tested by treating the willingness to pay values as sample observations. Connelly et al. (2004a, b) have found that the newly hired employees are willing to pay more than the other employees in his study. In contrast to that, this study suggests that newly hired employees are less likely to pay for childcare facilities compared to other employees.

The average willingness to pay values for voting yes for childcare in all three firms is substantially larger than the employees who voted no for that facility. This shows that employees' responses for contingent valuation method questions are consistent and meaningful. When considering the mean willingness to pay values by male employees and employees without children below the age of 16 years in company $\mathrm{C}$, it is higher than the female employees and employees with children below the age of 16. Employees without the direct benefit from the childcare facility may see the centre as a benefit because the absence of co-workers with children may increase the workload of other employees (Rothausen et al., 1998).

Further, the employees who live near the firm in all three firms are willing to pay a substantially higher value than the other employees. The employees who live closer to the firm are more likely to pay for the childcare facility as having the childcare centre near home is more preferable (Connelly et al., 2004a, b). In addition, the significance of the variables may not be common for all three firms.

\subsection{Probability of voting "yes" to pay for an on-site child care}

Table 6 shows the probability of voting yes to pay for an on-site childcare facility. It implies the same pattern as Table 5 .

When considering the full samples from the three firms, over $50 \%$ of employees have voted yes to pay for the childcare facility, and among the three firms, company $\mathrm{C}$ is more likely to vote yes to pay for the facility compared to the other two firms.

In both the companies $\mathrm{A}$ and $\mathrm{B}$, the employees without children below the age of 16 years are less likely to pay for the childcare facility, and it is significant in both firms. However, in company $\mathrm{C}$, employees without children below the age of 16 are more likely to pay for the childcare facility. These results equate the results from the study of McIntyre (2000). The study of McIntyre stated that at a Gallup poll in 1996, the employees were asked how much they were willing to contribute to an on-site childcare facility and $54 \%$ of the employees without children had voted to contribute something to the childcare facility.

When comparing the married and single employees, the married employees in all three firms are the most likely to pay for the childcare facility. In company $\mathrm{C}, 74.36 \%$ of the employees without children below the age of 16 that voted yes for the childcare facility were married employees. In company $\mathrm{C}$, the employees without children below the age of 16 years that voted yes are either the employees with children above 16 years or the employees expecting children.

As shown in Table 5, the employees who live closer to the firm are more likely to pay for the facility in all three firms. However, it is significant only in company A and company B.

\subsection{Sentiments of managers towards the on-site childcare facility}

Several supplementary discussions were carried out with managerial level workers of the companies without having childcare facilities to recognize how those managers think about establishing an on-site childcare facility. Another discussion was conducted with the human 
JABES

29,4

Table 6.

Probability of Voting

"Yes" to Pay for

Childcare Facility by

Selected

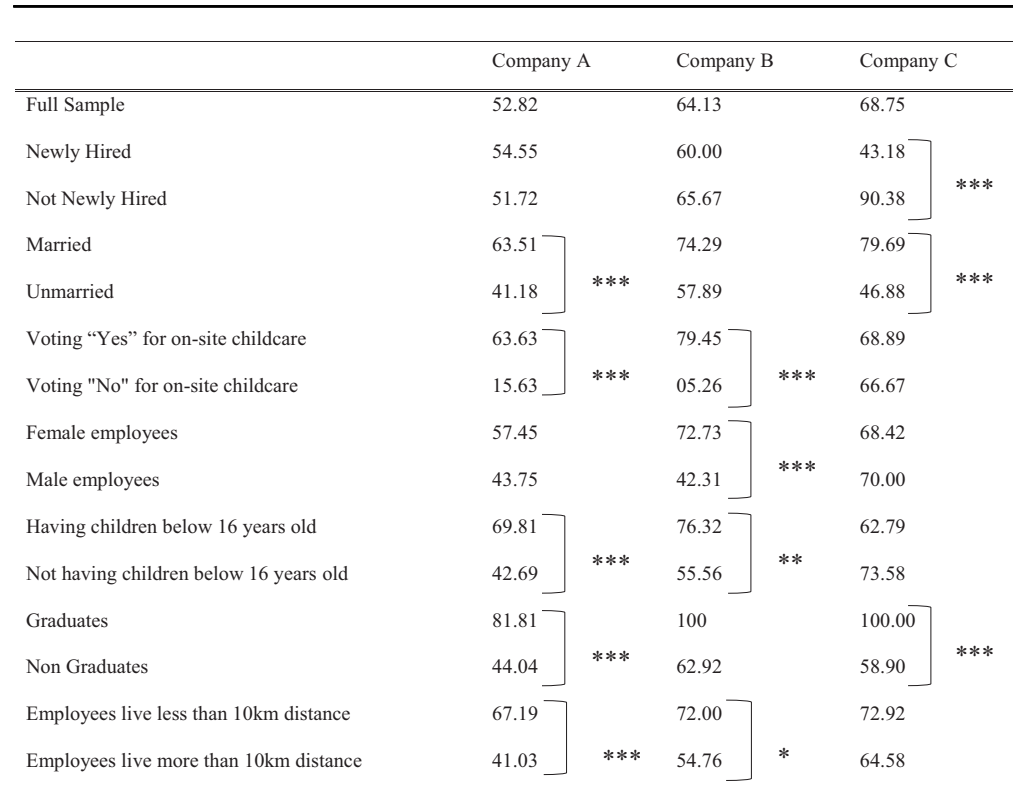

Characteristics

* Indicates that significant differences were found at the levels denoted below

*Significantly different at 10 percent level

$* *$ Significantly different at 5 percent level

****Significantly different at 1 percent level

Source(s): Authors' calculation based on survey data

resources manager of the company $\mathrm{C}$ to obtain the details of the already established child care facility of company $\mathrm{C}$. These supplementary discussions were held during the visits to conduct quantitative survey.

Managers of the firms without having on-site child care facilities mentioned that it is important to establish an on-site child care facility.

I think having an on-site childcare centre is more important for our company since there is a higher rate of absenteeism in female employees. The most common reason they give for their absence is, there was no one at home to take care of the child. We hope to provide a childcare facility through an on-site or near-site centre.

\section{(Quality Manager - Company A)}

It is very important to have an on-site childcare centre in the garment industry as the majority of the workers in the garment industry are female workers. Therefore, it is beneficial for working mothers to have a childcare centre at their workplace. (Production Manager - Company B)

We are planning to implement a childcare centre at our workplace as the absence of one employee might affect the workload of other employees. And there are so many complaints about this problem.

\section{(Human Resources Manager - Company B)}

There are not adequate policies for working women regarding childcare and childbirth besides maternity leave. Therefore, as a woman, I feel the importance of having an on-site childcare facility to reduce the stress of working mothers. 
(Assistant Production Manager - Company B)

The manager from company $\mathrm{C}$ provided the following details about firm's on-site child care facility.

Our on-site childcare centre was opened in 2016, and about 30 children are enrolled now. The child care centre is open on weekdays, and the firm does not provide the children's meals. The needed food and sanitary items should be provided by the guardian (mother or father) of the child. The firm offers a discount when multiple children are enrolling in the centre, and only the children who are above four months old can be enrolled in the centre.

Willingness to

pay for On-site Childcare

(Human Resources Manager - Company C)

\section{Conclusion and implications}

This study analyses the employees' preference for the on-site childcare facility. The mean willingness to pay for an on-site childcare facility is Rs. 1919.28 and Rs. 1657.93 per month in company A and company B, respectively. The mean willingness to pay in the company, which has an on-site childcare facility, is comparatively high with an amount of Rs. 3750.34 per month. The collected data of the study illustrate that an employee is willing to pay a higher amount when there is a high preference for on-site childcare. When evaluating the factors affecting the willingness to pay for childcare, the monthly income variable has a negative correlation in company $\mathrm{C}$. Moreover, the newly hired variable positively correlates with the willingness to pay in all three firms.

Therefore, this study implies that most employees in the three firms have a strong preference for implementation of an on-site childcare centre. This suggests that investing to provide childcare facilities at the workplace helps increase the women's labour participation, and it will assist to overcome the childcare barrier that most women are facing today. As this study concludes a low monetary value as the employee's willingness to pay for the facility, it will be more effective to execute an employer-sponsored childcare facility at the workplace.

This study is not free from limitations. The explorative discussions conducted with selected managers were supplementary to our quantitative analysis in the study. However, qualitative analysis using structured in-depth interviews with firm managers would be fruitful future research agenda. Many companies in the apparel industry manufacture many knitted clothing products such as shirts, sweaters, underwear and hosiery, and socks. However, this study was conducted for selected three reputed companies in the apparel industry. Therefore, the results can be generalized only to the three surveyed companies. To eliminate that limitation, this study can be further developed by targeting a specific district and collecting data from the general public using the current childcare market rate.

\section{References}

Anderson, B. and Geldenhuys, D.J. (2011), "The relationship between absenteeism and employersponsored childcare", Southern African Business Review, Vol. 15 No. 3, pp. 21-45.

Andersson, B.E. (1989), "Effects of public day-care: a longitudinal study", Child Development, pp. $857-866$.

Andersson, B.E. (1992), "Effects of day-care on cognitive and socio-emotional competence of thirteenyear-old Swedish schoolchildren”, Child Development, Vol. 63 No. 1, pp. 20-36.

Berniell, M.I. and Sánchez-Páramo, C. (2011), Overview of Time Use Data Used for the Analysis of Gender Differences in Time Use Patterns, Background Paper for the World Development Report 2012, World Bank Publications, Washington DC.

Blegen, M.A., Mueller, C.W. and Price, J.L. (1988), "Measurement of kinship responsibility for organization research", Journal of Applied Psychology, Vol. 73 No. 3, p. 402. 
JABES 29,4

Braun, C., Rehdanz, K. and Schmidt, U. (2016), "Validity of willingness to pay measures under preference uncertainty”, PloS One, Vol. 11 No. 4, p. e0154078.

Broberg, A.G., Wessels, H., Lamb, M.E. and Hwang, C.P. (1997), "Effects of day care on the development of cognitive abilities in 8-year-olds: a longitudinal study", Developmental Psychology, Vol. 33 No. 1, p. 62.

Cohen, J., Cohen, P., West, S.G. and Aiken, L.S. (2013), Applied Multiple Regression/correlation Analysis for the Behavioral Sciences, Routledge.

Chaudry, A., Pedroza, J.M., Sandstrom, H., Danzinger, A., Grosz, M., Scott, M. and Ting, S. (2011), "Child care choices of low income working families", Urban Institute, Washington DC.

Chen, F., Short, S.E. and Entwisle, B. (2000), "The impact of grandparental proximity on maternal childcare in China", Population Research and Policy Review, Vol. 19 No. 6, pp. 571-590.

Chowdhury, A.R. (2013), Low Female Labor Force Participation in Sri Lanka: Contributory Factors, Challenges and Policy Implications, The World Bank, Washington, D.C.

Compton, J. and Pollak, R.A. (2014), "Family proximity, childcare, and women' labor force attachment", Journal of Urban Economics, Vol. 79, pp. 72-90.

Connelly, R. (1992), "The effect of child care costs on married women's labor force participation", The Review of Economics and Statistics, Vol. 74 No. 1, pp. 83-90.

Connelly, R., DeGraff, D.S. and Willis, R.A. (2004a), "The value of employer-sponsored child care to employees", Industrial Relations: A Journal of Economy and Society, Vol. 43 No. 4, pp. 759-792.

Connelly, R., DeGraff, D.S. and Willis, R.A. (2004b), Kids at Work: The Value of Employer-Sponsored On-Site Child Care Centers, WE Upjohn Institute, Kalamazoo.

Demographic and Health Survey (2016), Department of Census and Statistics, Ministry of National Policies and Economic Affairs, Colombo.

Duflo, E. (2012), "Women empowerment and economic development”, Journal of Economic Literature, Vol. 50 No. 4, pp. 1051-1079.

Erel, O., Oberman, Y. and Yirmiya, N. (2000), "Maternal versus non maternal care and seven domains of children's development", Psychological Bulletin, Vol. 126 No. 5, p. 727.

Floge, L. (1989), "Changing household structure, child-care availability, and employment among mothers of preschool children", Journal of Marriage and Family, Vol. 51 No. 1, pp. 51-63.

Frone, M.R., Russell, M. and Cooper, M.L. (1992), "Antecedents and outcomes of work-family conflict: testing a model of the work-family interface”, Journal of Applied Psychology, Vol. 77 No. 1, p. 65.

Goff, S.J., Mount, M.K. and Jamison, R.L. (1990), "Employer supported child care, work/family conflict, and absenteeism: a field study", Personnel Psychology, Vol. 43 No. 4, pp. 793-809.

Hanemann, W.M. (1994), "Valuing the environment through contingent valuation", The Journal of Economic Perspectives, Vol. 8 No. 4, pp. 19-43.

Hein, C. and Cassirer, N. (2010), Workplace Solutions for Childcare, International Labour Office, Geneva.

Kealy, M.J. and Turner, R.W. (1993), "A test of the equality of closed-ended and open-ended contingent valuations", American Journal of Agricultural Economics, Vol. 75 No. 2, pp. 321-331.

Kossek, E.E. and Nichol, V. (1992), "The effects of On-site Child Care on employee attitudes and performance", Personnel Psychology, Vol. 45 No. 3.

Krejcie, R.V. and Morgan, D.W. (1970), "Determining sample size for research activities", Educational and Psychological Measurement, Vol. 30 No. 3, pp. 607-610.

Lobel, S.A. and Clair, L.S. (1992), "Effects of family responsibilities, gender, and career identity salience on performance outcomes", Academy of Management Journal, Vol. 35 No. 5, pp. 1057-1069.

McIntyre, L. (2000), "Childcare on board: the growth of work-site daycare", Regional Review, Q3, pp. 8-15. 
Milkovich, G.T. and Gomez, L.R. (1976), "Day care and selected employee work behaviors", Academy of Management Journal, Vol. 19 No. 1, pp. 111-115.

Miller, T.I. (1984), "The effects of employer-sponsored child care on employee absenteeism, turnover, productivity, recruitment or job satisfaction: what is claimed and what is known", Personnel Psychology, Vol. 37 No. 2, pp. 277-289.

Narayanan, S. (2008), "Employment guarantee, women's work and childcare”, Economic and Political Weekly, pp. 10-13.

O’Doherty, R.K. (1996), Planning, People and Preferences: A Role for Contingent Valuation, Gower House, Aldershot.

Rothausen, T.J., Gonzalez, J.A., Clarke, N.E. and O'DELL, L.L. (1998), "Family-friendly backlash-fact or fiction? The case of organizations on-site childcare centers", Personnel Psychology, Vol. 51 No. 3, pp. 685-706.

Samarakoon, S.J.M.N.G. and Mayadunne, G. (2018), "An explanatory study on low labor force participation of women in Sri Lanka”, Sri Lanka Journal of Social Sciences, Vol. 41 No. 2, pp. 137-151.

Solotaroff, J.L., Joseph, G., Kuriakose, A.T. and Sethi, J. (2020), Getting to Work: Unlocking Women's Potential in Sri Lanka's Labor Force, World Bank Publications, Washington.

Sri Lanka labor force survey (2019), Department of Census and Statistics, Ministry of Finance, Economy and Policy Development, Colombo.

Stolzenberg, R.M. and Waite, L.J. (1984), "Local labor markets, children and labor force participation of wives", Demography, Vol. 21 No. 2, pp. 157-170.

Waite, L.J., Haggstrom, G.W. and Kanouse, D.E. (1985), "Changes in the employment activities of new parents”, American Sociological Review, Vol. 50 No. 2, pp. 263-272.

\section{Corresponding author}

Asankha Pallegedara can be contacted at: asankap@wyb.ac.lk

For instructions on how to order reprints of this article, please visit our website:

www.emeraldgrouppublishing.com/licensing/reprints.htm

Or contact us for further details: permissions@emeraldinsight.com 